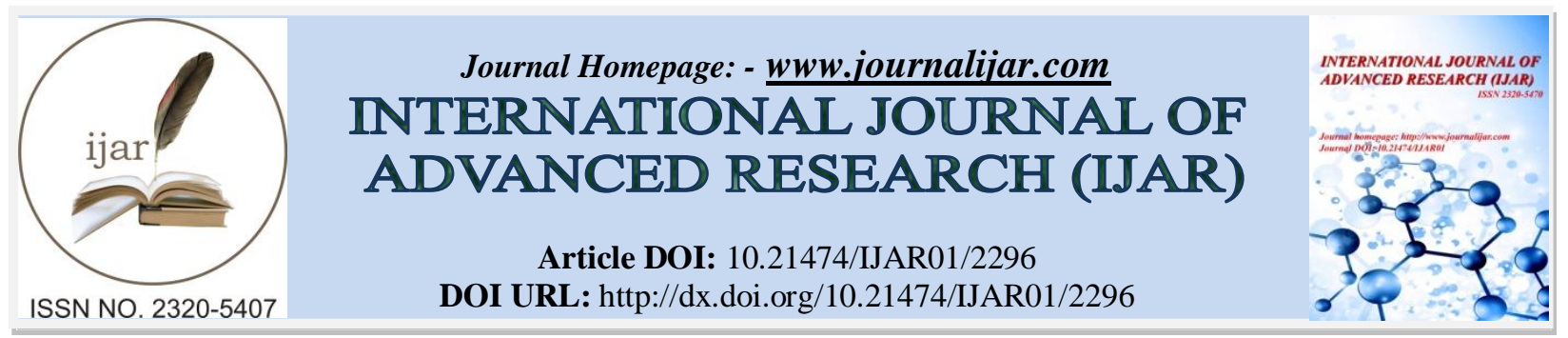

RESEARCH ARTICLE

\title{
KNOWLEDGE, ATTITUDE AND PRACTICE TOWARDS DYSLIPIDEMIA AMONG PATIENTS ATTENDING PRIMARY HEALTH CARE CENTERS, ABHA CITY, SAUDI ARABIA.
}

\author{
Asma Saad Alahmari ${ }^{1}$, Fatima Mohammed Alrashed1, Afnan Riyadh Awad1, Sabah Abdulrahman \\ Khozam1, Maram Mohammed Alshahrani1, Batool Ali Mahdi1, Saja Abdullah Alsanamah ${ }^{1}$, Maha \\ Mohammed Alshahrani ${ }^{2}$ and Yahia Mater AlKhaldi ${ }^{3}$. \\ 1. Interns, King Khalid University, Abha, Saudi Arabia. \\ 2. College of medicine, King Khalid University, Abha, Saudi Arabia. \\ 3. Research \& Studies Department, General Directorate of Health Affairs, MOH, Aseer, Saudi Arabia.
}

\section{Manuscript Info}

Manuscript History

Received: 29 September 2016

Final Accepted: 30 October 2016

Published: November 2016

Key words:-

Knowledge, attitude, practice, dyslipidemia, Primary health care center, Aseer

\section{Abstract}

Background:- Dyslipidemia has become noticeable in the Kingdom of Saudi Arabia (KSA), given the improvement of the economic status and accompanied socio-demographic, nutritional, and lifestyle changes in late decades together with a decreased burden of infectious diseases.

Objectives: To assess the knowledge, attitude and practice of adult patients attending primary health care centers in Abha city regarding dyslipidemia

Subjects and methods:- A cross-sectional study was conducted at primary health care centers in Abha City. There are 10 recognized centers at the time of the study.All adult Saudi patients (males and females), attending the centers, throughout the period of study conduction (August-September, 2016) were eligible for study inclusion. A simple random technique was applied to select 4 primary health care centers. A representative sample was chosen. A datacollection questionnaire was used included personal characteristics, knowledge about dyslipidemia, attitude toward dyslipidemia and its preventive measures.

Results:- The study included 361 adult Saudi patients. Their age ranged between 18 and 83 years with a mean $( \pm \mathrm{SD})$ of $36.4( \pm 14.9)$ years. Females represent $60.4 \%$. Their main source of information about dyslipidemia were physicians/nurses (30.1\%), internet (27.8\%) and media (24.8\%). Overall, $77.3 \%$ of the participants had poor knowledge about dyslipidemia.Educational level, job status and source of information were significantly associated with good knowledge. Negative attitude towards dyslipidemia and its management was reported by $47.4 \%$ of the participants. Patients with high educational level were more likely to have positive attitude toward dyslipidemia and its management compared to illiterates $(80 \%$ versus $23.5 \%$ ), $\mathrm{p}=0.012$. Regarding job status, medical professionals were more likely to have positive attitude toward dyslipidemia and its

Corresponding Author:- Asma Saad Alahmari.

Address:- Interns, King Khalid University, Abha, Saudi Arabia. 
management as opposed to retired participants (77.5\% versus $38.2 \%$ ), $\mathrm{p}=0.019$. Participants who had good dyslipidemia knowledge expressed positive attitude towards dyslipidemia and its management compared to those who had poor knowledge (67.1\% versus $48.6 \%$ ), $\mathrm{p}=0.003$. More than half of the participants checked their body weight within a month $(56.5 \%)$ whereas $34.3 \%$ measured their lipid profile within one year. Good compliance with balanced diet was reported by only $9.1 \%$ of the respondents.

Conclusion:- Knowledge about, attitude towards and practicing related to dyslypidemia were inadequate among adult Saudi patients attending primary health care centers in Abha. The causes of this gap between knowledge, attitude and practice need to be identified and intervened.

Copy Right, IJAR, 2016,. All rights reserved.

\section{Introduction:-}

Dyslipidemia is a disorder of lipoprotein metabolism, including lipoprotein overproduction or deficiency. Dyslipidemia may be expressed by rising of the total cholesterol, the low-density lipoprotein (LDL) and the triglyceride concentrations, and a reduction in the high-density lipoprotein (HDL) concentration in the blood. ${ }^{1}$

Dyslipidemiais one of the most significant risk factors for many chronic non-communicable diseases winding up in serious morbidity, and mortality and medical costs worldwide. ${ }^{2-4}$ As the result of improvement of economic status and sedentary lifestyles, this condition has become one of the serious health problem in Saudi Arabia. ${ }^{5}$

The prevalence of dyslipidemia ranges due to the racial, socioeconomic, and cultural characteristics of particular population groups. ${ }^{6}$ Evaluating the prevalence, perception of risk factors, and predictors of this situationare of cardinal value for preventing and controlling the disease and its sequelae. ${ }^{6}$ A few studies have lately discussed prevalence and predictors of this issue in the KSA. ${ }^{7-10} \mathrm{Up}$ to our knowledge, no studies have evaluated the perception of primary health care patients of the issue.

Various factors and reasons can cause an abnormality in the degrees of lipids in the blood and include hereditary causes, nutrition, sedentary lifestyle,age, gender andtype II diabetes..$^{11-13}$

This study aimed to assess the knowledge, attitude and practice of adult patients attending primary health care centers in Abha city regarding dyslipidemia.

\section{Subject and methods:-}

This cross-sectional study was conducted at primary health care centers in Abha City, which is the capital of Aseer Region. All adult Saudi patients (males and females), attending the ten PHCCs in Abha city were eligible for study inclusion, belonging to Ministry of Health throughout the period of study conduction were eligible for study inclusion.

Based on thorough review of relevant literature, the researchers constructed the questionnaire. It includes personal characteristics, knowledge about dyslipidemia, attitude toward dyslipidemia and its preventive measures.A score of " 1 " was assigned to a correct response to a knowledge item, while a score of " 0 " was assigned to wrong or do not know response. The knowledge of those whose score was $\geq 60 \%$ were considered as "good"; while those whose score was $<60 \%$ were considered as "poor". Attitude was assessed using a 5-point likert scale, i.e., strongly agree, agree, not sure, disagree, and strongly disagree. Attitude was classified to: positive attitude and negative attitude depending on the median of the total score of the five questions assessing the attitude. Those with scores equal median score or more were considered to have positive attitude while those with less than the median score were considered to have negative attitude. Body mass index was classified as underweight $\left(<18.5 \mathrm{~kg} / \mathrm{m}^{2}\right)$, normal $(18.5-$ $\left.24.9 \mathrm{~kg} / \mathrm{m}^{2}\right)$, overweight $\left(25-29.9 \mathrm{~kg} / \mathrm{m}^{2}\right)$ and obese $\left(>30 \mathrm{~kg} / \mathrm{m}^{2}\right)$. 
The questionnaire was validated by three consultants (two were family medicine and one was internal medicine).A pilot study was carried out on a purposive sample of 20 patients attending one of the PHC centers in Abha, whose data was not included in the main study. The purpose of this pilot study was to test the wording and reliability of questions. Before start of the study, permissions from local authority and local Research and Ethics committee were obtained. Statistical Package for Social Sciences (SPSS) software version 22.0 was used for data entry and analysis. Descriptive statistics (number, percentage for categorical variables and mean, standard deviation and range for continuous variables) and analytic statistics using Chi Square tests $(\chi 2)$ to test for the association and/or the difference between two categorical variables were applied. P-value less than 0.05 was considered statistically significant.

\section{Results:-}

The study included 361 adult Saudi patients. Their personal characteristics are summarized in Table 1. Their age ranged between 18 and 83 years with a mean $( \pm \mathrm{SD})$ of $36.4( \pm 14.9)$ years. Females represent $60.4 \%$ of them. More than half of them (59\%) were married. Approximately half of them $49.9 \%$ were university graduated, $23.8 \%$ were house wives, and $11.4 \%$ were medical professionals (physicians and nurses)

Itwasobserved thatonly $17.7 \%$ of the participants have enough information whereas $56 \%$ reported having some information about dyslipidemia. The sources of information were from physicians/nurses $(30.1 \%)$, internet $(27.8 \%)$ and media $(24.8 \%)$ as illustrated in Figure 1.

Table 2 summarizes the responses of the participants to knowledge related questions regarding dyslipidemia. The percentage of correct answers ranged between $86.7 \%$ for knowing that regular physical activity as a measure of prevention of dyslipidemia to $21.6 \%$ for knowing that reducing TV watching could prevent dyslipidemia.

Overall, $77.3 \%$ of the participants had poor knowledge regarding dyslipidemia as shown in figure 2.

It was found that educational level, job status and source of information were significantly associated with good knowledge regarding dyslipidemia. Half of participants with high qualification (50\%) compared to $11.8 \%$ of illiterates had good dyslipidemia knowledge, $\mathrm{p}=0.001$. More than half of medical professionals $(53.7 \%)$ compared to $8.3 \%$ of military people and none of business men had good knowledge regarding dyslipidemia, $\mathrm{p}<0.001$. Regarding source of information, those who had their information from symposium/lectures were more likely to have good knowledge than those who had their information from the Internet $(39.1 \%$ versus $7.5 \%), \mathrm{p}<0.001$.

Negative attitude towards dyslipidemia and its management was reported among $47.4 \%$ of the participants. Participants with high qualification were more likely to have positive attitude toward dyslipidemia and its management compared to illiterates $(80 \%$ versus $23.5 \%), \mathrm{p}=0.012$. Regarding job status, medical professionals were more likely to have positive attitude toward dyslipidemia and its management as opposed to retired participants (77.5\% versus $38.2 \%), \mathrm{p}=0.019$. Participants who had good dyslipidemia knowledge expressed more positive attitude towards dyslipidemia and its management compared to those who had poor knowledge $(67.1 \%$ versus $48.6 \%$ ), $\mathrm{p}=0.003$ ( Table 4 ).

Table 5 summarizes the practice of the participants regarding dyslipidemia management. More than half of them assessed their body weight within a month $(56.5 \%)$ whereas $34.3 \%$ assessed their lipid profile within one year. Physical activities were practiced by almost half of them (49.6\%), mainly walking (66.5\%). Almost half of the participants (48\%) reported daily physical activity. The duration of practicing physical activity daily ranged between 2 and 180 minutes with mean \pm SD of $44.0 \pm 31.7$ minutes. Good compliance with balanced diet was reported by $9.1 \%$ of the respondents.Daily intake of vegetables/fruits was reported by $23.3 \%$ of the participants. Taking antidyslipidemia drugs was reported by $18.6 \%$ of the participants. The duration of taking anti-dyslipidemia drugs ranged between one month and 17 years with a mean of $5.5 \pm 4.0$ years. 
Table 1:- Personal characteristics of the participants.

\begin{tabular}{|l|l|l|l|}
\hline & Categories & Frequency & Percentage \\
\hline Age in years & $18-30$ & 168 & 46.5 \\
& $31-50$ & 122 & 33.8 \\
& $>50$ & 71 & 19.7 \\
\hline Gender & Male & 143 & 39.6 \\
& Female & 218 & 60.4 \\
\hline Marital status & Married & 213 & 59.0 \\
& Single & 148 & 41.0 \\
\hline Educational level & Illiterate & 17 & 4.7 \\
& Primary school & 25 & 6.9 \\
& Intermediate school & 33 & 9.1 \\
& High school & 86 & 23.8 \\
& University & 180 & 49.9 \\
& Postgraduate & 20 & 5.5 \\
\hline Job status & Student & 82 & 22.7 \\
& House wife & 86 & 23.8 \\
& Teacher & 52 & 14.4 \\
& Governmental employee & 40 & 11.1 \\
& Medical professional & 41 & 11.4 \\
& Business & 14 & 3.9 \\
& Military & 12 & 3.3 \\
& Retired & 34 & 9.4 \\
\hline
\end{tabular}

Table 2:- Knowledge of dyslipidemia among the participants.

\begin{tabular}{|l|l|l|}
\hline \multicolumn{2}{|l|}{ Correct answer } & Percentage \\
\cline { 2 - 3 } Dyslipidemia appear in the following features & Number & 23.8 \\
Increase in LDL cholesterol and triglycerides and decrease in HDL & 86 & \\
cholesterol levels & & 28.3 \\
\hline The highest serum normal cholesterol level is & 102 & 78.7 \\
200 mg/dl & & \\
\hline Among food staffs rich in cholesterol & 284 & \\
Egg yolk, shrimp, animal fats & & 75.6 \\
\hline The factors associated with dyslipemedia includes & 62.5 \\
Low physical activity & & 79.2 \\
Diabetes mellitus & 273 & 56.5 \\
Obesity & 225 & \\
Genetic predisposition & 286 & 65.4 \\
\hline Diseases that can be caused by dyslipedemia includes & 204 & 74.0 \\
Heart attach & & 61.5 \\
Atherosclerosis & 236 & \\
Fatty liver & 267 & 86.7 \\
\hline It is possible to prevent obesity/dyslipedemia by: & 222 & 69.8 \\
Regular physical activity & & 80.3 \\
Increase vegetable intake & 313 & 21.6 \\
Walking/sports & 252 & \\
Reduce TV watching & 290 & 78 \\
\hline
\end{tabular}


Table 3:- Factors associated with knowledge of dyslipidemia among the participants.

\begin{tabular}{|c|c|c|c|}
\hline & \multicolumn{2}{|c|}{ Dyslipidemia knowledge level } & \\
\hline & $\begin{array}{c}\text { Poor } \\
\mathrm{N}=279\end{array}$ & $\begin{array}{c}\text { Good } \\
\mathrm{N}=82\end{array}$ & \\
\hline $\begin{array}{l}\text { Age (years) } \\
18-30(\mathrm{n}=168) \\
31-50(\mathrm{n}=122) \\
>50(\mathrm{n}=71)\end{array}$ & $\begin{array}{c}122(72.6) \\
100(82.0) \\
57(80.3)\end{array}$ & $\begin{array}{l}46(27.4) \\
22(18.0) \\
14(19.7)\end{array}$ & 0.137 \\
\hline $\begin{array}{l}\text { Gender } \\
\text { Male }(n=143) \\
\text { Female }(n=218)\end{array}$ & $\begin{array}{l}112(78.3) \\
167(76.6)\end{array}$ & $\begin{array}{l}31(21.7) \\
51(23.4)\end{array}$ & 0.703 \\
\hline $\begin{array}{l}\text { Marital status } \\
\text { Married }(n=213) \\
\text { Single }(n=148)\end{array}$ & $\begin{array}{l}170(79.8) \\
109(73.6)\end{array}$ & $\begin{array}{l}43(20.2) \\
39(26.4)\end{array}$ & 0.169 \\
\hline $\begin{array}{l}\text { Education } \\
\text { Illiterate }(\mathrm{n}=17) \\
\text { Primary school }(\mathrm{n}=25) \\
\text { Intermediate school }(\mathrm{n}=33) \\
\text { High school }(\mathrm{n}=86) \\
\text { University }(\mathrm{n}=180) \\
\text { Postgraduate }(\mathrm{n}=20)\end{array}$ & $\begin{array}{c}15(88.2) \\
23(92.0) \\
30(90.9) \\
72(83.7) \\
129(71.7) \\
10(50.0)\end{array}$ & $\begin{array}{c}2(11.8) \\
2(8.0) \\
3(9.1) \\
14(16.3) \\
51(28.3) \\
10(50.0)\end{array}$ & 0.001 \\
\hline $\begin{array}{l}\text { Job } \\
\text { Student }(n=82) \\
\text { House wife }(n=86) \\
\text { Teacher }(n=52) \\
\text { Governmental employee }(n=40) \\
\text { Medical professional }(n=41) \\
\text { Business }(n=14) \\
\text { Military }(n=12) \\
\text { Retired }(n=34) \\
\end{array}$ & $\begin{array}{l}70(85.4) \\
72(83.7) \\
38(73.1) \\
32(80.0) \\
19(46.3) \\
14(100) \\
11(91.7) \\
23(67.6) \\
\end{array}$ & $\begin{array}{c}12(14.6) \\
14(16.3) \\
14(26.9) \\
8(20.0) \\
22(53.7) \\
0(0.0) \\
1(8.3) \\
11(32.4) \\
\end{array}$ & $<0.001$ \\
\hline $\begin{array}{l}\text { Source of information } \\
\text { Internet }(n=67) \\
\text { Friends }(n=29) \\
\text { Symposium/lectures }(n=23) \\
\text { Media }(n=25) \\
\text { Newspapers/magazines }(n=17) \\
\text { Physicians/nurses }(n=34) \\
\text { More than one source }(n=166)\end{array}$ & $\begin{array}{c}62(92.5) \\
24(82.8) \\
14(60.9) \\
17(68.0) \\
11(64.7) \\
26(76.5) \\
125(75.3)\end{array}$ & $\begin{array}{c}5(7.5) \\
5(17.2) \\
9(39.1) \\
8(32.0) \\
6(35.0) \\
8(23.5) \\
41(24.7)\end{array}$ & 0.013 \\
\hline $\begin{array}{l}\text { Body mass index } \\
\text { Underweight }(n=28) \\
\text { Normal }(n=127) \\
\text { Overweight }(n=96) \\
\text { Obese }(n=108)\end{array}$ & $\begin{array}{l}26(92.9) \\
96(75.0) \\
70(72.9) \\
86(79.6)\end{array}$ & $\begin{array}{c}2(7.1) \\
32(25.0) \\
26(27.1) \\
22(20.4)\end{array}$ & 0.132 \\
\hline
\end{tabular}


Table 4:- Factors associated with attitude towards dyslipidemia among the participants.

\begin{tabular}{|c|c|c|c|}
\hline & \multicolumn{2}{|c|}{ Attitude towards Dyslipidemia } & \\
\hline & $\begin{array}{c}\text { Negative } \\
\mathrm{N}=171\end{array}$ & $\begin{array}{c}\text { Positive } \\
\mathrm{N}=190\end{array}$ & \\
\hline $\begin{array}{l}\text { Age (years) } \\
18-30(n=168) \\
31-50(n=122) \\
>50(n=71)\end{array}$ & $\begin{array}{l}71(42.3) \\
65(52.9) \\
35(49.3)\end{array}$ & $\begin{array}{l}97(57.7) \\
57(47.1) \\
36(50.7)\end{array}$ & 0.188 \\
\hline $\begin{array}{l}\text { Gender } \\
\text { Male }(n=143) \\
\text { Female }(n=218)\end{array}$ & $\begin{array}{c}68(47.2) \\
103(47.2)\end{array}$ & $\begin{array}{c}75(52.8) \\
115(52.8)\end{array}$ & 0.990 \\
\hline $\begin{array}{l}\text { Marital status } \\
\text { Married }(n=213) \\
\text { Single }(n=148)\end{array}$ & $\begin{array}{c}109(51.2) \\
62(41.5)\end{array}$ & $\begin{array}{c}104(48.8) \\
86(58.5)\end{array}$ & 0.071 \\
\hline $\begin{array}{l}\text { Education } \\
\text { Illiterate }(\mathrm{n}=17) \\
\text { Primary school }(\mathrm{n}=25) \\
\text { Intermediate school }(\mathrm{n}=33) \\
\text { High school }(\mathrm{n}=86) \\
\text { University }(\mathrm{n}=180) \\
\text { Postgraduate }(\mathrm{n}=20)\end{array}$ & $\begin{array}{l}13(76.5) \\
13(52.0) \\
19(56.3) \\
44(51.2) \\
78(43.3) \\
4(20.0)\end{array}$ & $\begin{array}{c}4(23.5) \\
12(48.0) \\
14(43.7) \\
42(48.8) \\
102(56.7) \\
16(80.0)\end{array}$ & 0.012 \\
\hline $\begin{array}{l}\text { Job } \\
\text { Student }(\mathrm{n}=82) \\
\text { House wife }(\mathrm{n}=86) \\
\text { Teacher }(\mathrm{n}=52) \\
\text { Governmental employee }(\mathrm{n}=40) \\
\text { Medical professional }(\mathrm{n}=41) \\
\text { Business }(\mathrm{n}=14) \\
\text { Military }(\mathrm{n}=12) \\
\text { Retired }(\mathrm{n}=34)\end{array}$ & $\begin{array}{l}40(48.8) \\
45(52.3) \\
23(44.2) \\
22(55.0) \\
9(22.5) \\
4(28.6) \\
6(50.0) \\
21(61.8)\end{array}$ & $\begin{array}{l}42(51.2) \\
41(47.7) \\
29(55.8) \\
18(45.0) \\
32(77.5) \\
10(71.4) \\
6(50.0) \\
13(38.2)\end{array}$ & 0.019 \\
\hline $\begin{array}{l}\text { Source of information } \\
\text { Internet }(\mathrm{n}=67) \\
\text { Friends }(\mathrm{n}=29) \\
\text { Symposium/lectures }(\mathrm{n}=23) \\
\text { Media }(\mathrm{n}=25) \\
\text { Newspapers/magazines }(\mathrm{n}=17) \\
\text { Physicians/nurses }(\mathrm{n}=34) \\
\text { More than one source }(\mathrm{n}=166)\end{array}$ & $\begin{array}{c}33(49.3) \\
17(57.1) \\
7(30.4) \\
8(32.0) \\
8(47.1) \\
16(47.1) \\
82(49.4) \\
\end{array}$ & $\begin{array}{l}34(50.7) \\
12(42.9) \\
16(69.9) \\
17(68.0) \\
9(52.9) \\
18(52.9) \\
84(50.6) \\
\end{array}$ & 0.374 \\
\hline $\begin{array}{l}\text { Body mass index } \\
\text { Underweight }(\mathrm{n}=28) \\
\text { Normal }(\mathrm{n}=127) \\
\text { Overweight }(\mathrm{n}=96) \\
\text { Obese }(\mathrm{n}=108) \\
\end{array}$ & $\begin{array}{l}18(64.3) \\
50(39.4) \\
50(52.1) \\
52(48.1)\end{array}$ & $\begin{array}{l}10(35.7) \\
77(60.6) \\
46(47.9) \\
56(51.9)\end{array}$ & 0.061 \\
\hline $\begin{array}{l}\text { Dyslipidemia knowledge } \\
\text { Poor }(\mathrm{n}=278) \\
\text { Good }(\mathrm{n}=82)\end{array}$ & $\begin{array}{c}143(51.4) \\
27(32.9)\end{array}$ & $\begin{array}{c}135(48.6) \\
55(67.1)\end{array}$ & 0.003 \\
\hline
\end{tabular}


Table 5:- Practice of the participants regarding prevention and management of dyslipidemia.

\begin{tabular}{|l|l|l|l|}
\hline & Categories & Frequency & Percentage \\
\hline Last time you assessed body & Within a month & 204 & 56.5 \\
& $1-3$ months & 76 & 21.1 \\
& $>3$ months-one year & 48 & 13.3 \\
& >one year & 33 & 9.1 \\
\hline Last time you assessed lipid & Within one year & 124 & 34.3 \\
profile & More than one year & 78 & 21.6 \\
& Never & 159 & 44.0 \\
\hline Practicing physical activity & Yes & 179 & 49.6 \\
& No & 182 & 50.4 \\
\hline Type of physical *activity & Walking & 119 & 66.5 \\
(n=179) & Running & 50 & 27.9 \\
& Swimming & 20 & 11.2 \\
& Football & 10 & 5.6 \\
& Volleyball & 3 & 1.7 \\
& Others & 11 & 6.1 \\
\hline Frequency of practicing physical & Daily & 86 & 48.0 \\
activity & Twice weekly & 73 & 40.8 \\
& Once weekly & 20 & 11.2 \\
\hline Compliance with balanced diet & Never & 58 & 16.1 \\
& Rarely & 100 & 27.7 \\
& Sometimes & 170 & 47.1 \\
& Always & 33 & 9.1 \\
\hline Frequency of eating & Daily & 84 & 23.3 \\
vegetables/fruits per week & Day after day & 104 & 28.8 \\
& Twice weekly & 95 & 26.3 \\
& Once weekly & 64 & 17.7 \\
\hline Taking anti-dyslipidemic drugs & Never & Yes & 14 \\
& No & 67 & 3.9 \\
\hline
\end{tabular}

* More than one answer is possible (sum exceeds 100\%)

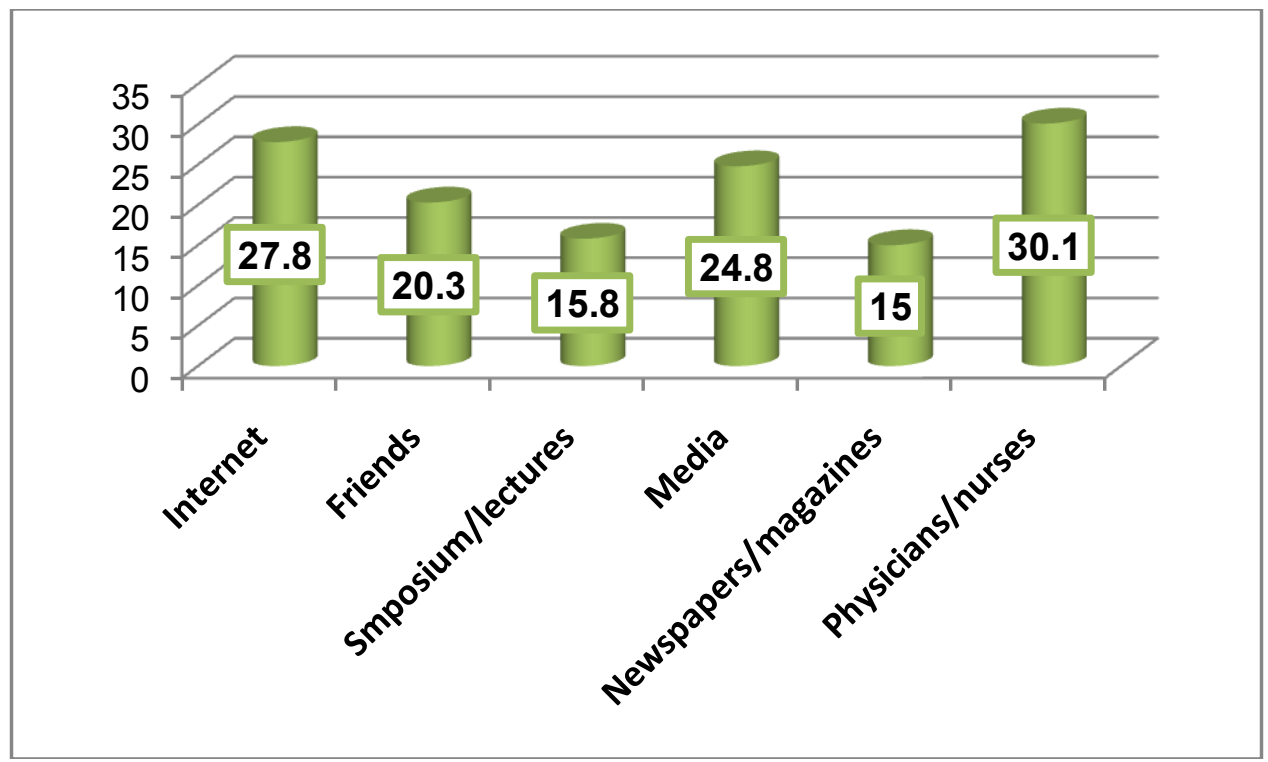

Figure 1:- Source of information about dyslipedemia among the participants. 


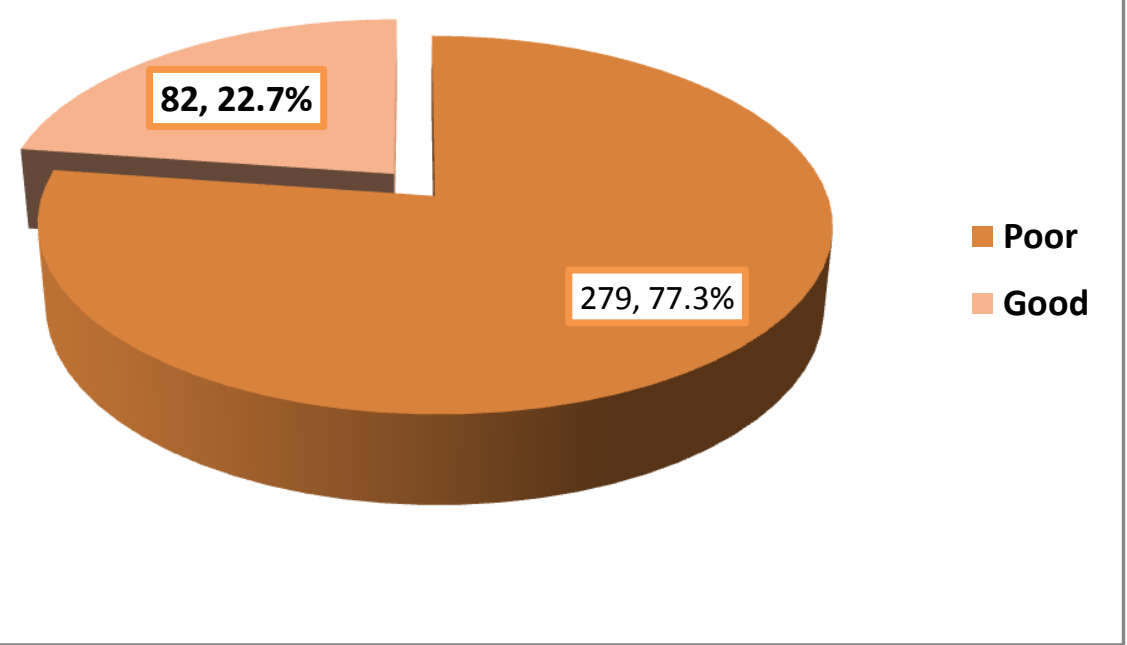

Figure 2:- Knowledge level regarding dyslipedemia among the participants.

\section{Discussion:-}

With economic growth and associated changes in lifestyle and diet, the level of lipid profile in the Saudi population has greatly increased. ${ }^{5}$

Dyslipidemia is a major risk factor for atherosclerosis, and cardiovascular disease such as coronary heart disease and stroke. ${ }^{16-18}$ Increasing the awareness and knowledge of patients regarding dyslipidemia risk factors and management has a positive impact on cardiovascular disease prevention. ${ }^{19}$

In the current study, most of the participants $(77.3 \%$ ) had poor knowledge regarding dyslipidemia and $47.4 \%$ had negative attitude. Several studies have revealed almost the same including a study carried out in European countries ${ }^{20}$ and studies carried out among Chinese population ${ }^{21-23}$ Despite that that dyslipidemia is an important health risk factor in our community, many important facts related to dyslipidemia was unknown by most of the participants which emphasizes the vital roles of dissemination of health education related to dyslipidemia.

Patients with inadequate knowledge of dyslipidemiausuallyhave poor attitude towards it and consequently are more non-compliant patients regarded drug. ${ }^{24}$ In accordance with that, thisstudy revealed a significant association between good dyslipidemia knowledge and positive attitude and vice versa.

The present study revealed that higher educated patients were more likely to have good knowledge and positive attitude towards dyslipidemia compared to less educated patients. Numerous recent studies showed that education is positively associated with the awareness of and attitude towards dyslipidemia. ${ }^{21,25-28}$

Regarding job status, as expected, medical professionals expressed higher significant knowledge of and attitude towards dyslipidemia compared with military persons and businessmen. This may be related to the possibility that militaries and businessmen havingless time to focus on their health, and tend to seek late management of any adverse health condition.

The main sources of information about dyslipidemia in the present study were physicians and internet. However, the highest rate of good knowledge regarding dyslipidemia was reported among those attended symposium/lectures whereas the lowest rate was reported among those whose source of information was the internet. Therefore, physicians should pay more attention in giving accurate information to their patients as well as official internet websites sited with accurate information about dyslipidemia should be provided and supervised.

Dyslipidemia is almost asymptomatic and requires blood analysis for its detection which in most cases requested by a physician. ${ }^{21}$ The results of the present study revealed that almost one third of patients had lipid profile in the last year. This is in line with another study carried out in China. ${ }^{26}$ This means that a considerable proportion of our 
populations areconcerned about their health, particularly being concerned about cardiovascular diseases. Whether they did it by themselves or requested by physicians to be investigated.

Practice of the participants regarding prevention of dyslipidemia is adequate in some aspects as half of them assessed their body weight within the last month, one third assessed lipid profile within one year, half practiced physical activities. However, it was inadequate in some other aspects as only $9.1 \%$ were always compliant with and less than one-quarter consumed vegetables/fruits on daily basis. The findings should be interpreted with an understanding of the following possible limitations. The cross-sectional nature of this study design means that causal associations can only be made with caution. As in many surveys, the definitions of dyslipidemia knowledge, attitudeand practice were based on information taken during a single visit, therefore it is subjected to recall bias of self-reported information.

In conclusion, knowledge about dyslipidemia, attitude towards it and practicing related to it are overall inadequate among adult Saudi patients attending primary health care centers in Abha, The causes of this gap between knowledge, attitude and practice need to be identified and intervened.

\section{References:-}

1. Ahmed SM, Clasen ME, Donnelly JF. Management of dyslipidemia in adults. AmFam Physician. 1998 May 57(9):2192-2204

2. World Health Organization, "Quantifying Selected Major Risks to Health," World Health Organization, Geneva, 2002.

3. Smith D. Epidemiology of Dyslipidemia and Economic Burden on the Healthcare System. American Journal of Managed Care 2007; 13(S3):S68-S71.

4. Stamler J, Daviglus ML, Garside DB, Dyer AR, Greenland P, et al. Relationship of Baseline Serum Cholesterol Levels in 3 Large Cohorts of Younger Men to Long-Term Coronary, Cardiovascular, and All-Cause Mortality and to Longevity. The Journal of the American Medical Association. 2000;284(3):311-318.

5. WHO. Country Cooperation Strategy for WHO and Saudi Arabia 2006-2011, 2012. Available at: http://www.who.int/countryfocus/cooperation_strategy/ccs_sau_en.pdf

6. Al-Kaaba AF, Al-Hamdan NA, El Tahir A, Abdalla AM, Saeed AA, Hamza MA. Prevalence and Correlates of Dyslipidemia among Adults in Saudi Arabia: Results from a National Survey. Open Journal of Endocrine and Metabolic Diseases 2012; 2: 89-97

7. Al-Nozha MM, Arafah MR, Al-Maatouq MA, MKhalil MZ, Khan NB, K. Al-Marzouki K, et al. Hyperlipidemia in Saudi Arabia.Saudi Medical Journal 2008;29(2): 282-287.

8. Ogbeide DO, Karim A, Al-Khalifa IM, Siddique S. Population-Based Study of Serum Lipid Levels in Al-Kharj Health Center, Saudi Arabia. Saudi Medical Journal. 2004;25(12): 1855-1857.

9. Al-Shehri SN, Saleh ZA, Salama MM, Hassan YM. Prevalence of Hyperlipidemia among Saudi School Children in Riyadh. Annals of Saudi Medicine. 2004;24(1): 6-8.

10. Abalkhail BA, Shawky S, Ghabrah TM, Mila WA. Hypercholesterolemia and 5-Year Risk of De- development of Coronary Heart Disease among University and School Workers in Jeddah, Saudi Arabia. American Journal of Preventive Medicine. 2000;31(4):390-395.

11. EremC,HacihasanogluA,DegerO,KocakM,TopbasM.Prevalence of dyslipidemia and associated risk factors among Turkish adults: Trabzon lipid study. Endocrine. 2008 Aug-Dec;34(1-3):36-51.

12. Félix-Redondo FJ,GrauM,Fernández-Bergés D. Cholesterol and cardiovascular disease in the elderly. Facts and gaps. Aging Dis. 2013 Mar 1;4(3):154-69.

13. CeskaR,VrablíkM,Sucharda P. Dyslipidemia and obesity 2011. Similarities and differences. VnitrLek. 2011 Mar;57(3):248-53.

14. Wadwa RP, Kinney GL, Maahs DM, Snell-Bergeon J, Hokanson JE, Garg SK, et al. Awareness and treatment of dyslipidemia in young adults with type 1 diabetes. Diabetes Care. 2005 May; 28(5):1051-6.

15. Online Roasoft sample size calculator. Available at: http://www.raosoft.com/samplesize.html.

16. Deng B, Luo T, Huang Y, Shen T, Ma J. Prevalence and determinants of hyperlipidemia in moderate altitude areas of the yunnan-kweic how plateau in southwestern china. High Alt Med Bio 2012, 13(1):13-21.

17. Wang S, Xu L, Jonas JB, You QS, Wang YX, Yang H. Prevalence and associated factors of dyslipidemia in the adult Chinese population. PLoS One 2011; 6(3):e17326.

18. Luo JY, Ma YT, Yu ZX, Yang YN, Xie X, Ma X, et al. Prevalence, awareness, treatment and control of dyslipidemia among adult in Northwestern China: the cardiovascular risk survey. Lipids Health Dis 2014; 13(1):4. 
19. Janus ED, Tideman PA, Dunbar JA, Kilkkinen A, Bunker SJ, Philpot B, et al.Dyslipidaemia in ruralAustralia: prevalence, awareness, and adherence to treatment guidelinesin the greater green triangle risk factor study. Med J Aust 2010; 192(3):127-132.

20. Alkerwi A, Pagny S, Lair ML, Delagardelle C, Beissel J. Level of unawareness and management of diabetes, hypertension, and dyslipidemia among adults in Luxembourg: findings from ORISCAV-LUX study. PLoS One 2013; 8(3):e57920.

21. He H, Yu Y-Q, Li Y, Kou C-G, Li B, Tao Y-C,et al. Dyslipidemia awareness, treatment, control and influence factors among adults in the Jilin province in China: a cross-sectional study. Lipids Health Dis. 2014; 13: 122.

22. Li JH, Wang L, Mi SQ, Zhang M, Jiang Y, Xu Y, et al. Awarenessrate, treatment rate and control rate of dyslipidemia in Chinese adults,2010. Chin J Prev Med 2012; 46(8):687-691.

23. Cai L, Zhang L, Liu A, Li S, Wang P. Prevalence, awareness, treatment, andcontrol of dyslipidemia among adults in Beijing, China. J AtherosclerThromb 2011; 19(2):159-168.

24. HariBabu R, Nagaraju R, Prasad KVSRG, Sureshwar Reddy M. Knowledge, Attitude and Practices of Hyperlipidaemia patients in a tertiary care setting. International Journal of Innovative Pharmaceutical Research. 2012; 3(2):208-211.

25. McDonald M, Hertz RP, Unger AN, Lustik MB. Prevalence, awareness, andmanagement of hypertension, dyslipidemia, and diabetes among UnitedStates adults aged 65 and older. J Gerontol A BiolSci Med Sci 2009; 64(2):256-263.

26. Fu YY, Yu JM, Wang JH, Sun YH, Liu HF, Hu DY. Factors associated withdyslipidemia awareness among residents in Beijing: results from CCEIP.Chin J Practical Intern Med 2010; 30(01):38-40.

27. Upadhyay UD, Waddell EN, Young S, Kerker BD, Berger M, Matte T, et al. Prevalence, awareness, treatment, and control of high LDLcholesterol in New York City, 2004. Prev Chronic Dis 2010; 7(3):A61.

28. Frontini MG, Srinivasan SR, Elkasabany A, Berenson GS. Awareness ofhypertension and dyslipidemia in a semirural population of youngadults: the Bogalusa heart study. Prev Med 2003; 36(4):398-402. 